\title{
ARTICLE
}

\section{Scents and Sensibilities: Interwar Lublin's Courtyards}

\author{
Stephanie Weismann \\ Center for the History of Transformations (RECET), Spitalgasse 2, Hof 1.1., A-1090 Wien \\ stephanie.weismann@univie.ac.at
}

From horse dung to garlic, olfactory debates raged in interwar Poland. Smells are ubiquitous and substantially influence how we perceive the atmosphere of a given place. This article focuses on 'smell affairs' and olfactory sensibilities that were emerging in the city of Lublin in Poland after 1918. In particular, it addresses what Lublin's courtyard smells tell us about the condition, development and mindset of a Polish city at that time. On their way into the 'modern' era, Lublin's citizens began to complain about rural elements interfering with the 'metropolitan' character of Lublin as well as how 'ethnic smells' of fellow Jewish citizens would intrude upon the air of 'their' 'Polish' city. Poking one's nose into the air and the 'smellscapes' of the urban courtyard, one can observe what was regarded as a part, or not, of a modern city in independent Poland.

A distinct smell scenery characterised the urban courtyards of the Polish city of Lublin in the interwar period. Pungent odours were a constant concern reflected both in the files of the municipality's Sanitary Commission as well as in articles in the local newspapers. In 1928 the main Lublin daily Ziemia Lubelska complained:

There are courtyards haunted by such a smell that you would risk fainting if you passed them without a handkerchief pressed to your nose. This stench stems from toilets, which are in a state of terrible neglect, as well as from waste bins without cover whose garbage ferments and rots for weeks under the windows of its unhappy dwellers. ${ }^{1}$

Due to the dense living conditions, the main smell characteristics of Lublin's courtyards in the first half of the twentieth century were of the outhouse, with its notorious cesspool, and garbage dumps. This odoriferous scenery was frequently enriched by the keeping of poultry, pigs and dogs. Furthermore, the courtyard served as a spatial extension of small businesses and workshops: the backdoors of private butchers and ragmen, bakeries and other small enterprises usually opened into the courtyard, as did their garbage, chimneys and, thus, odours.

Smells are ubiquitous and they substantially influence how we perceive the atmosphere of a given place. We often, mostly unconsciously, evaluate persons, situations and our environment through the nose. By asking what smells and who smells, we can locate environmental conditions as well as intercultural sensitivities, since smells are particularly powerful in the transmission of cultural values and social classifications. ${ }^{2}$ This article discusses selected urban scents and sensibilities, in particular what Lublin's courtyard smells tell us about the condition, development and mindset of a Polish city in the interwar period. Sniffing out what was in the air, here, provides insights not only into cultural practices of everyday life, but also into the motions and tensions of modernisation and the emotions of nation

\footnotetext{
1 Ziemia Lubelska (ZL), 30 Mar. 1928, 2.

2 See Constance Classen, David Howes and Anthony Synnott, Aroma: The Cultural History of Smell (London: Taylor \& Francis Group, 1994); Mark M. Smith, Sensory History (Oxford: Berg, 2007), on 'smelling' 59-74. 
building. The way people perceive, react to and talk about smells reveals much about subtle sentiments. Although definitions of pleasant or unpleasant air seem to be a subjective, individual mode of perception, smell perception is very much culturally marked. Furthermore, smells have been used to advance various socio-political agendas. A sensory history approach provides (cultural) historians with a greater understanding of the embodied experience of urbanisation as well as of the dynamics of nation building and inter-ethnic relations. Focusing on the public efforts of the municipality and the private concerns of Lublin's inhabitants regarding smell issues, this article draws on local newspapers from the interwar period and archival records of the city of Lublin, including reports from the Sanitary Commission and complaints of Lublin's citizens submitted to the city's Public Health Department. ${ }^{3}$ This hubbub of civic objections illuminates the intensive negotiations regarding the city's (olfactory) transformation in the interwar period.

After Poland gained independence in 1918 the city of Lublin emerged as an urban centre and the regional capital of a mainly agricultural area. Largely due to an influx of impoverished people from the countryside searching for jobs in the city, its inhabitants increased by over 50 per cent between 1914 and 1931. With about 35 per cent of city dwellers identifying as Jewish, Lublin enjoyed the typical ethnic structure of a city in the region at that time. ${ }^{4}$ This article demonstrates how certain smell sensitivities reflect major infrastructural as well as ideological notions occurring in post-independence Poland. In this context, the prevalent smell issues range from decomposing garbage to olfactory resentments regarding fellow Jewish citizens.

\section{The Prospects of Urban Smellscapes}

The concept of smellscapes ${ }^{5}$ implies that 'smells may be space-related. Continents, countries, regions, neighbourhoods and houses' each 'have their particular smellscapes'. ${ }^{6}$ So, too, do cities. Urban 'smellscapes' are influenced by the level of industrialisation, forms of habitation, sanitation practices, cooking customs and seasonal cycles, among other factors. ${ }^{7}$ Certain parts of a city - markets, industrial zones, train stations - can be identified by the characteristic scents associated with the activities performed there as well as with people living there, especially 'ethnic' neighbourhoods. ${ }^{8}$ Thus, 'we see the city we hear the city, but above all we smell the city'. ${ }^{9}$ Invoking the senses challenges the understanding of city life, as the perception of urban 'smellscapes' fundamentally responds to and reflects changing political, economic and social orders. ${ }^{10}$ Sniffing out changes in urban space ambiances is rewarding because

3 The local (daily) newspapers consulted include the conservative Ziemia Lubelska as well as the National Democrat's Głos Lubelski. Unfortunately, the main local Yiddish daily Lubliner Tugblat for the period in question (late 1920s to early 1930s) is not available as it has been lost. See Adam Kopciowski, 'Wos hert zich in der prowinc?' Prasa żydowska na Lubelszczyźnie i jej największy dziennik 'Lubliner Tugblat' (Lublin: Wydawnictwo UMCS, 2015). The local leftish press (both in Yiddish and in Polish), instead, was highly focused on political and/or party issues and hardly concerned with everyday life issues and urban nuisances, thus providing less references to everyday life and the sensory perception of city life at that time. Also, the abovementioned dailies had a broader coverage than the leftish press, thus being more representative regarding dominant contemporary discourses.

4 See Tadeusz Radzik, 'Społeczność żydowska Lublina w międzywojennym dwudziestoleciu. Obraz statistyczny', in Tadeusz Radzik, ed., Żydzi w Lublinie. Materiały do dziejów społeczności żydowskiej Lublina (Lublin: Wydawn. Uniwersytetu Marii Curie-Skłodowskiej, 1995), 143-53, 146.

5 J. Douglas Porteous, 'Smellscape', in Jim Drobnick, ed., The Smell Culture Reader (Oxford: Berg, 2006), 89-106.

6 Ibid., 96.

7 Jim Drobnick, 'Toposmia: Art, Scent, and Interrogations of Spatiality', Angelaki: Journal of Theoretical Humanities, 7, 1 (2002), 33.

8 Jonathan Reinarz, Past Scents: Historical Perspectives on Smell (Chicago: University of Illinois Press, 2014); see also Kelvin E. Y. Low, 'Rumination on Smell as a Sociocultural Phenomenon', Current Sociology, 53 (2005).

9 Victoria Henshaw, Urban Smellscpapes: Understanding and Designing City Smell Environments (London: Routledge, 2014), book back cover.

10 John Urry, 'City Life and the Senses', in Gary Bridge and Sophie Watson, eds., A Companion to the City (Oxford: Blackwell, 2008), 395. 
'sensual relations are most of all social relations'. ${ }^{11}$ The 'sensory turn' in the humanities and social sciences in the 1990s prompted various theorists to open up the human sensorium to social and cultural analysis. ${ }^{12}$ Urban 'sensescape' studies have become a fruitful avenue of research recent years. ${ }^{13}$ The urban olfactory sensorium has been studied extensively in a range of different contexts, such as public health, ${ }^{14}$ architecture, ${ }^{15}$ literature ${ }^{16}$ and art, ${ }^{17}$ and includes studies of cities, such as Paris, ${ }^{18}$ Vienna, ${ }^{19}$ Grenoble, ${ }^{20}$ Frankfurt, ${ }^{21}$ Bangkok, ${ }^{22}$ Singapore, ${ }^{23}$ St Petersburg, ${ }^{24}$ Moscow, ${ }^{25}$ Sheffield and Manchester, ${ }^{26}$ Montréal and Brussels, ${ }^{27}$ Chicago, ${ }^{28}$ London $^{29}$ and England more generally. $^{30}$

11 David Howes, Sensual Relations: Engaging the Senses in Culture and Social Theory (Ann Arbor: University of Michigan Press, 2010), 55.

12 Alain Corbin, The Foul and the Fragrant: Odor and the French Social Imagination (Cambridge: Harvard University Press, 1988); David Howes, The Varieties of Sensory Experience: A Sourcebook in the Anthropology of the Senses (Toronto: University of Toronto Press, 1991); Constance Classen, Worlds of Sense: Exploring the Senses in History and Across Cultures (London: Routledge, 1993); Paul Rodaway, Sensuous Geographies (London: Routledge, 1994); Classen, Howes and Synnott, Aroma.

13 See Ivan Illich, "'The Dirt of Cities", "The Aura of Cities", “The Smell of the Dead”, and "Utopia of an Odourless City", in Malcom Miles, Tim Hall and Iain Borden, eds., The City Cultures Reader (London: Routledge, 2000); Mirko Zardini and Wolfgang Schivelbusch, eds., Sense of the City: An Alternate Approach to Urbanism (Montréal: Canadian Centre for Architecture, 2005); Kimberly DeFazio, The City of the Senses: Urban Culture and Urban Space (New York: Palgrave Macmillan, 2011).

14 Corbin, Foul; Reinarz, Past Scents.

15 Suzel Balez, 'Characterisation of an Existing Building According to Olfactory Parameters', paper presented at 'Architectural and Urban Ambient Environment', workshop held at Nantes, France, Feb. 2002, available at https:// halshs.archives-ouvertes.fr/halshs-00596759/document [3.Febr.2020]; Juhani Pallasmaa, The Eyes of the Skin: Architecture and the Senses (New York: Wiley, 2012).

16 H. J. Rindisbacher, The Smell of Books: A Cultural-Historical Study of Olfactory Perception in Literature (Ann Arbor: University of Michigan Press, 1993); Janice Carlisle, Common Scents: Comparative Encounters in High-Victorian Fiction (Oxford: Oxford University Press, 2004); Elżbieta Rybicka, 'Sensoryczna geografia literacka', in Elżbieta Konończuk and Elżbieta Sidoruk, eds., Przestrzenie geo(bio)graficzne $w$ literaturze (Białystok: Wydawnictwo Uniwersytetu w Białymstoku, 2015).

17 Jim Drobnick, 'Volatile Effects: Olfactory Dimension of Art and Architecture', in David Howes, ed., Empire of the Senses: The Sensual Culture Reader (Oxford: Berg, 2005).

18 Corbin, Foul; David S. Barnes, The Great Stink of Paris and the Nineteenth-Century Struggle Against Filth and Germs (Baltimore: John Hopkins University Press, 2018); Lucile Grésillon, 'Sentir Paris: Itinéraire Méthodologique', Strates, 11 (2004).

19 Peter Payer, Der Gestank von Wien. Über Kanalgase, Totendünste und andere üble Geruchskulissen (Wien: Döcker, 1997); Mădălina Diaconu and Lukas Marcel Vosicky, 'Gerüche des öffentlichen Raums zwischen Raumcharakteren und Sozialpraktiken', in Mădălina Diaconu et al., eds., Sensorisches Labor Wien. Urbane Haptik- und Geruchsforschung (Wien: LiT, 2011).

20 Nathalie Poiret, 'Odeurs impures. Du corps humain à la cité (Grénoble, Xviiie - Xixe Siècle)', Terrain, 31 (1998).

21 Werner Bischoff, 'Ein Hauch von Großstadt - Überlegungen zum urbanen Geruchsraum', in Jürgen Hasse, ed., Subjektivität in der Stadtforschung (Frankfurt/M.: Institut für Didaktik der Geographie, 2002).

22 Erik Cohen, 'The Broken Cycle. Smell in a Bangkok Lane', in Jim Drobnick, ed., The Smell Culture Reader (Oxford: Berg, 2006).

23 Martin F. Manalansan, 'Immigrant Lives and the Politics of Ofaction in the Global City', in Drobnick, ed., The Smell Culture Reader; Kelvin E.Y. Low, 'Presenting the Self, the Social Body, and the Olfactory: Managing Smells in Everyday Life Experience', Sociological Perspectives, 49, 4 (Winter 2006).

24 Vladimir Lapin, Peterburg: zapakhy $i$ zvuki (St. Petersburg: Evropeysky dom, 2007).

25 Alexander M. Martin, 'Sewage and the City: Filth, Smell, and Representations of Urban Life in Moscow, 1770-1880', The Russian Review, 67, 2 (2008), 243-74.

26 Henshaw, Urban Smellscpapes.

27 Nicholas Kenny, The Feel of the City: Experiences of Urban Transformation (Toronto: University of Toronto Press, 2014).

28 Adam Mack, Sensing Chicago: Noisemakers, Strikebreakers, and Muckrakers (Urbana, IL: University of Illinois Press, 2015).

29 Stephen Halliday, The Great Stink of London: Sir Joseph Bazalgette and the Cleansing of the Victorian Capital (Stroud: The History Press, 2011).

30 William Tullett, Smell in Eighteenth-Century England: A Social Sense (Oxford: Oxford University Press, 2019). 
Urban smell-studies have enriched our knowledge of urban experience, everyday city life and how the senses shape our perception of a city. However, few scholars have applied the sensory history approach $^{31}$ to the (cultural) history of East-Central Europe, ${ }^{32}$ although that approach promises profound insights into the dynamics of specific local sensitivities as well as political and socio-cultural transformations. The city of Lublin in today's eastern Poland is highly representative of the shifting political and socio-cultural landscape of East-Central Europe in the twentieth century. It serves as a case study of how hygiene, health and odoriferous rhetoric started to matter in public discourse in interwar Poland and how one can understand certain socio-political transformations through everyday smell matters. Since health was of immediate relevance to the new state, odours played a crucial role, for example, in the process of raising public awareness about the importance of hygiene. ${ }^{33}$ Odour discussions also contributed to people's growing awareness of urban living conditions, citizens' rights and the definition of what was considered urban or rural. Thus, odours mattered greatly in the process of modernisation, but they also played a crucial role in the demarcation of what or who belonged to the city or was considered the 'other'. Studying smells provides an alternative urban history, showing that everyday smell discourse is tightly related to the notions of urbanisation and civic emancipation, to the emotions of nation building and to the nature of interwar Polish anti-Semitism.

\section{The City of Lublin and Its (Odour) Nuisances}

The city of Lublin has undergone substantial transformations under different regimes. A key place of trade at the crossroads between Warsaw and Lvov in the sixteenth century, Lublin lost its significance over the centuries. As a consequence of the partition of Poland between Prussia, the Habsburg Empire and Tsarist Russia, Lublin was incorporated into Congress Poland (or Russian Poland) in 1815, at which point the city finally lost contact with other important parts of the former Polish state. Located at the margins of this Russian-ruled territory, Lublin did have access to the large domestic market of Russia; however, the city also found itself peripheral and neglected by the Tsarist authorities when it came to infrastructure. ${ }^{34}$ With Polish independence in 1918 Lublin moved from the periphery to the centre of the newly established Second Polish Republic. As the capital of a largely rural region it gained significance as an urban centre. By fighting 'backwardness' and striving to have a metropolitan air, Lublin perfectly reflects the troubled, yet 'ordinary' history of a city in the region. After the First World War Lublin developed a visible (multi-)cultural life, becoming the sixth largest city in Poland. It emerged as an educational centre and university town: the Catholic University was founded in 1918 (building on Lublin's traditional status as a centre of Catholicism), and Europe's largest Talmud School opened in 1930 (continuing Lublin's centuries-long tradition as a centre of Hasidism). ${ }^{35}$ In 1914

31 Smith, Sensory History; Jan-Friedrich Missfelder, 'Ganzkörpergeschichte: Sinne, Sinn und Sinnlichkeit für eine Historische Anthropologie', Internationales Archiv für Sozialgeschichte der deutschen Literatur, 39, 2 (2014), 457-75; Mark S. R. Jenner, 'Follow Your Nose? Smell, Smelling, and Their Histories', The American Historical Review, 116, 2 (Apr. 2011), 335-51.

32 With a few exceptions, see, for example, Matthew P. Romaniello and Tricia Starks, eds., Russian History through the Senses: From 1700 to the Present (London: Bloomsbury Academic, 2016); Ol'ga Vaynshteyn, ed., aromaty i zapakhi $v$ kul'ture. Kniga 2 (Moskva: Novoye literaturnoye obozreniye, 2010); Maria Pirogovskaya, 'Odour of Chlorine in Soviet Urban Reality: Notes on the Clean and the Collective', in Robert Beck, Ulrike Krampl and Emmanuelle Retaillaud-Bajac, eds., Les cinq sens de la ville $d u$ Moyen Âge á nos jours (Tours: Presses universitaires François-Rabelais, 2013), 199-210; Włodzimierz Pessel, Antropologia nieczystości. Studia z kultury sanitarnej Warszawy (Warszawa: Trio and Collegium Civitas, 2010); Mariya Pirogovskaya, Miazmy, simptomy, uliki. Zapakhi mezhdu meditsinoy i moral'yu v russkoy kul'ture vtoroy poloviny XIX veka (St.Peterburg: Izdatel'stvo Evropeyskogo universiteta v Sankt-Peterburge, 2018).

33 See also Tricia Starks, The Body Soviet: Propaganda, Hygiene, and the Revolutionary State (Madison: University of Wisconsin Press, 2009); Marta Aleksandra Balinska, 'The National Institute of Hygiene and Public Health in Poland 1918-1939', Social History of Medicine, 9, 3 (1996).

34 See Jörg Gebhard, Lublin. Eine polnische Stadt im Hinterhof der Moderne (1815-1914) (Köln: Böhlau, 2006).

35 Konrad Zieliński and Nina Zielińska, Jeszywas Chachmej Lublin: Uczelnia Mędrców Lublina (Lublin: Wydaw. Uniw. Marii Curie-Skłodowskiej, 2003). 
Lublin had 80,000 inhabitants. By 1931 the population had grown to 124,600 because of migration from the countryside. The city hosted at least seven cinemas and two theatres, which offered not only the classical repertoire and movies but also a highly varied programme of cabaret and dancing events in both Polish and Yiddish. Lublin's interwar press was blooming with the relaxation of censorship since 1905. Besides the conservative Ziemia Lubelska and the rather nationalist Głos Lubelski (a daily newspaper supporting the National Democrats), Lublin had at least eleven other local dailies and several smaller satirical or literary journals. The four Jewish newspapers (three of them in Yiddish) reflected the wide range of political engagement among one third of Lublin's inhabitants, from the Bundist Unzer Expres to the assimilationist Myśl Żydowska in Polish. Lublin hosted several elegant coffee houses and their usual circle of poets and actors and well-stocked bookstores. Despite its blossoming cultural and educational life, ${ }^{36}$ Lublin struggled with the usual issues of the time and region, such as postponed sanitary reforms, the influx of uneducated people from the countryside, overcrowding due to the lack of housing space (and with this, the spread of epidemics) and a dilapidated Old Town. ${ }^{37}$

Over the course of the nineteenth century, housing in the neglected Old Town became increasingly unsuitable. The 'better off Lublin citizens settled, instead, in the western areas, where a new part of the city was laid out along the main promenade (Krakowskie Przedmieście) with its coffee houses and hotels. Even so, in 1924 just 857 of 3,648 houses had running water. In 1928 only thirty-two houses were connected to the newly built sewage system; ${ }^{38}$ in 1930, it was only 20 per cent. ${ }^{39}$ Most of Lublin's inhabitants still used the outhouse in the courtyard and carried water in buckets from one of the numerous public wells. Soapsuds and dishwater, besides other everyday waste, were usually emptied into the open gutter (rynsztok) in the courtyard or onto the street. The stench of this wastewater from herring marinade to kitchen refuse to human waste - led to increasing complaints about Lublin's 'backward' smell-scenery in the local press. Thus, it was the sense of smell, primarily, that motivated urbanists and social reformers to take action. ${ }^{40}$ Smells are ubiquitous and have a pervasive and invisible presence that is difficult to regulate, and, as a result, have been a major concern in the process of monitoring, structuring and disciplining the 'modern' city. ${ }^{41}$

Over the course of the late eighteenth and early nineteenth centuries, views about the 'smellscapes' of major European cities altered gradually. Miasmatic theory - with its strong awareness of (the menace of) smells, linking disease to both human and animal waste - raised a new public awareness and at some point lead to a 'faecal crisis' in the minds of many people. ${ }^{42}$ In the second half of the nineteenth century, London (1858) and Paris (1880) fought their 'Great Stinks' caused by accumulated human excrement which stimulated a flurry of official reports and media articles. ${ }^{43}$ For Lublin, this crisis

\footnotetext{
36 Tadeusz Radzik, 'W latach dwudziestlecia międzywojennego. Życie kulturalne', in Radzik Tadeusz, ed., Lublin. Dzieje Miasta. XIX i XX Wiek (Lublin: Multico, 2000).

37 See also Anna Veronika Wendland, “Europa” zivilisiert den "Osten”: Stadthygienische Interventionen, Wohnen und Konsum in Wilna und Lemberg 1900-1930’, in Alena Janatková and Hanna Kozińka-Witt, eds., Wohnen in der Großstadt 1900-1939 (Stuttgart: Franz Steiner, 2006).

38 Sprawozdania i statystyka działność sanitarna Magistrata, 1928-1930, APL [Archiwum Panstwowe w Lublinie/Lublin State Archive] 354030.7.2.5.392, 5.

39 The first water supply system was introduced in 1899 by Adolf Weisblat, the next major expansion of the city's water and sewage system was conducted 1925-9. See J. Marczuk, 'Budowa i rozwój urządzeń komunalnych w Lublinie w latach 1925-1929', Kwartalnik historii kultury materialnej, 4 (1978), 505-6.

40 See Georg Simmel, Soziologie der Sinne [1908], Gesamtausgabe, Bd.11 (Frankfurt/Main: Suhrkamp, 1992). Also Corbin, Foul.

41 Urry, 'City Life', 393.

42 Christopher Hamlin, Public Health and Social Justice in the Age of Chadwick: Britain, 1800-1854 (Cambridge: Cambridge University Press, 1998); Halliday, Great Stink; Barnes, Great Stink; Inglis David, 'Sewers and Sensibilities: The Bourgeois Faecal Experience in the Nineteenth-Century City', in Alexander Cowan and Jill Steward, eds., The City and the Senses: Urban Culture since 1500 (Aldershot: Ashgate, 2007).

43 David S. Barnes, 'Confronting Sensory Crisis in the Great Stinks of London and Paris', in William A. Cohen and Ryan Johnson, eds., Filth. Dirt, Disgust, and Modern Life (Minneapolis: University of Minnesota Press, 2005).
} 
became salient after 1918. Although miasma theory - which held that 'bad air' caused diseases - had been long since disproven by Pasteur's germ theory, bad smells were still considered a threat to health. ${ }^{44}$ Moreover, 'bad smells' were also perceived as a threat to modernity in so far as 'modernity' was understood to include controlling putrid air as well as overseeing people and minds through public instructions. ${ }^{45}$ The nineteenth-century trend of enforcing orderliness and hygiene was well received all over Europe; in East-Central Europe, though, it gained footing substantially after 1918 with the birth of nations.

Alongside many other cities in former Congress Poland, ${ }^{46}$ in 1925 Lublin's city authorities launched a major sanitation project concerned with hygiene and de-odourising the city. Regulating the city's odours, mostly caused by the problematic sewage situation, was fundamental in the attempt to give the city a more refined appearance. Having gained independence from Russian rule, Lublin strove to catch up with other major Polish cities (with different histories of urbanisation under Prussian, Habsburg and Tsarist rule ${ }^{47}$ ) and to achieve a metropolitan air. ${ }^{48}$

In 1925 the Association of Polish Town Planners (Towarzystwo Urbanistów Polskich) announced an 'urban competition' for 'Great Lublin' ${ }^{\text {,9 }}$ that occurred within a wider context of a Poland- and Europe-wide reform discourse on urban development and urban sanitation. ${ }^{50}$ Lublin's municipality desired the city to undergo a 'civilising process', and its discourse was all about 'hygienising, regulating and sanitising. ${ }^{51}$ The master plan foresaw the 'revision, amelioration and orderliness' of 'Great Lublin' to make it a 'modern' city of 'new relevance' and 'representative character' ${ }^{52}$ Lublin's air would be relieved of the stenches of 'backwardness', embodied, among others, by organic smells. Urban planning has possessed a strong focus on odour control and odour management. Regulating the city's smells was a fundamental part of the attempt to give the city an ambience similar to other major (European) cities in the region. In 1924 Głos Lubelski lamented 'how far we are still from Europe, ${ }^{53}$ describing the miasmas and unpleasant smells spread by Lublin's refuse service. Despite all efforts, in 1930 Ziemia Lubelska was still complaining that 'Lublin, the Voivodship-capital, has theatres, cultural societies, universities and heaps of muck on its streets: can you imagine something like this in Warsaw, Lvov or Cracow? In Lublin, yes. The gutters and sinks draining into the streets are full of domestic filth coated with muck. ${ }^{54}$

The hygienisation and deodorisation projects performed by Lublin's municipality in the interwar period encompassed sewage policies, the regulation of the refuse service, the paving of streets, the

\footnotetext{
44 See Barnes, Great Stink, chapter on 'Odors and "Infection" - 1880 and Beyond', 229-59.

45 See Jan C. Behrends and Martin Kohlrausch, eds., Races to Modernity: Metropolitan Aspirations in Eastern Europe, 1890 1940 (Budapest: Central European University Press, 2014). See also Khaled Fahmy, 'An Olfactory Tale of Two Cities: Cairo in the Nineteenth Century', in George T. Scanlon and Jill Edwards, eds., Historians in Cairo: Essays in Honor of George Scanlon (Cairo: American University in Cairo Press, 2002), 168.

46 Ignacy Kędzierski, 'Jak będzie wyglądał przyszły Wielki Lublin. Wyjątki z konkursu na szkic regulacyjny m.Lublina', Przegląd lubelsko-kresowy, 11/12 (1925).

47 In the Habsburg ruled Polish territories urbanisation attempts were initiated earlier; Cracow was the first Polish city to undergo a regulation plan (1909-12).

48 See Nathaniel D. Wood, Becoming Metropolitan: Urban Selfhood and the Making of Modern Cracow (DeKalb: Northern Illinois University Press 2004). See also Kathryn Ciancia, 'Borderland Modernity: Poles, Jews, and Urban Spaces in Interwar Eastern Poland', The Journal of Modern History, 89, 3 (2017).

49 Program Konkursu nr 1 TUP w Warszawie na szkic regulacji i zabudowy miasta Lublina, konkurs na szkic regulacji miasta Lublina, 1925, see Natalia Przesmycka, Lublin. Przeobrażenia Urbanistyczne 1915-1939 (Lublin: Polytechnika Lubelska, 2012), 156.

50 See Wendland, “'Europa”; Behrends and Kohlrausch, Races; Wood, 'Becoming Metropolitan'.

51 See Kędzierski, 'Jak będzie wyglądał'.

52 In 1931 the 'Plan of Great Lublin' (Plan Wielkiego Miasta Lublina) brought definite guidelines regarding shaping the development of the city.

53 Głos Lubelski (GL), 6 Apr. 1824, 3.

54 ZL, 1930, cited after Marta Denys, Lublin między wojnami. Opowieść o życiu miasta 1918-1939 (Lublin: Dom Wydawniczy Księży Młyn, 2010), 70.
} 
re-routing of rivers and attempts to improve city parks and greenery. ${ }^{55}$ Lublin was provided with a sewage system, water supply, a public slaughterhouse and a central electricity plant. 'Great Lublin' would become a sanitised, healthy and clearly structured Polish city regarding its infrastructure as well as, eventually, its social-ethnic structure. In this context, the Public Health Department was a major player in Poland's interwar politics and urban policies. The application of public health measures functioned as a site of emergence for the modern state. ${ }^{56}$ Public health served ideological ends by setting normative values in terms of behaviour, consumption, physical fitness and relations of the majority toward minority groups. ${ }^{57}$ Thus, the Sanitary Commission - a subdivision of the Public Health Department - tried to establish modern standards of hygiene, fighting epidemics and unsanitary conditions. The Commission regularly published 'urban codes of conduct', providing information about sanitary rules and sanitary obligations. ${ }^{58}$ They passed strict prohibitions against polluting staircases, courtyards, sidewalks, streets and squares with garbage, kitchen waste, sputum or excrement. ${ }^{59}$ Their directives reflect the actual, pressing sanitary problems typical for many mediumsized European cities at that time. Every paragraph of this 'code of conduct' testifies that emptying chamber pots into yards and onto the street, spitting in public and disposing various refuse in the courtyard was common. Regular inspection tours by sanitary commissioners served the purposes of litter and odour control. Newspapers were full of names and addresses 'called to account for unsanitary disorder'. ${ }^{60}$ This common measure of public accusations was aimed at disciplining people, but without much success. Even Krakowskie Przedmieście - where the nice coffeehouses, luxurious hotels and the well-provided general stores were located, and where elegant couples strolled on weekends could not avoid having its courtyard secretions discredit the beautiful facades: 'you only have to pass a few of the buildings on our "main" street to get vertigo from all these reeking exudations which the poor tenants have to smell day and night'. ${ }^{61}$ This elegant boulevard was haunted by the effluvia of poor courtyard facilities, that is, from the notorious common outhouse. Newspapers increasingly complained about the smell and about the municipality's odoriferous refuse policies:

The sanitation carts are standing in front of house number 30 at half past ten. The stench on the street is unbearable! The passers-by, returning at this time from the cinema, are many, they hold their noses and hasten away. But the smells are spreading all around Krakowskie Przedmieście like poison gas. You would think that the city centre should in every case be an adornment, as it serves representative purposes. . . Lublin must be worth belonging to the circle of Poland's ten biggest cities. ${ }^{62}$

The smell of faeces on the prestigious Krakowskie Przedmieście did not fit into the picture of a prospering, Voivodship capital of the newly established Second Polish Republic. Judging by reports and newspaper complaints, violations of hygiene instructions were a daily occurrence.

\footnotetext{
55 This 'konkurs' culminated in a loan (2,858,000 USD in Złoty) from the US company Ulen \& Co which held contracts to rebuild the water and sewage systems for ten major Polish cities on the territory of former Congress Poland - fighting the infrastructural 'legacy' of Russian ruled partitioned Poland. See Józef Marczuk, 'Budowa i rozwój urządzeń komunalnych w Lublinie w latach 1925-1939’, Kwartalnik historii kultury materialnej, 4 (1978).

56 Peter Atkins, 'Animal Wastes and Nuisancees in Nineteenth-Century London', in Peter Aktins, ed., Animal Cities: Beastly Urban Histories (London: Routledge, 2012), 27.

57 Katrin Steffen, 'Who Belongs to the Healthy Body of the Nation? Health and National Integration in Poland and the Polish Army after the First World War', in Heike Karge, Friederike Kind-Kovács and Sara Bernasconi, eds., From the Widwife's Bag to the Patient's File: Public Health in Eastern Europe (Budapest: Central European University Press, 2017), 121.

58 i.e. Regulamin sanitarno-porządkowy, 1935, APL 352207.6.2.1.2501.

59 Dziennik Zarządu m.Lublina, 25 Jul. 1934, no.5, 1209.

60 i.e. GL, 12 Nov. 1922, 4.

61 ZL, 4 Jul. 1929.

62 ZL, 3 Apr. 1927, 3.
} 
Public health reform owes its origins to concerns about stench and the demand for fresh air. ${ }^{63}$ Consequently, Lublin's Sanitary Commission ${ }^{64}$ was engaged in fighting bad odours by running inspection tours concerning the cleanliness of streets, buildings, grocery stores and, above all, courtyards. A district penal administrative advisor from the Sanitary Commission would hand out penalties on site if necessary. ${ }^{65}$ On 1 June 1928 a Lublin newspaper announced that the Sanitary Commission was carrying out a three-day lustration of urban housing in the context of an all-Polish supervisory action. ${ }^{66}$ Lustrations would include admonitions and deadlines for improving conditions. ${ }^{67}$

Judging by the on-going number of penalties and complaints as well as accusations and interventions, the sanitary situation in Lublin did not significantly improve. ${ }^{68}$ The protocols of the Sanitary Commission frequently mention that (olfactory) crime scenes were inspected repeatedly, however, often without improvement. ${ }^{69}$ Property owners would often refuse to follow the rules. ${ }^{70}$ However, the intensive discussion of these shortcomings in the local press was accompanied by a growing awareness not only of the 'shameful' condition of Lublin's 'smellscapes' ('unbelievable facts of sloppiness and contempt', as one local newspaper noted in 1931) but also of the relevance of hygiene and the notion of 'public health'.

The urban courtyard or podwórko, characterised by wooden galleries leading to the outside entrances of apartments, was a major element of Lublin's urban architecture in the interwar period. A podwórko was a semi-public space where private activities and public policies interacted. Organ-grinders, cutlers and rag-pickers used to fill the courtyards with their advertising singsong. ${ }^{72}$ Horse carts and stables frequently occupied the courtyards near market places together with laundry on the galleries and children playing in the yard. ${ }^{73}$ In the house gate that connected the courtyard with the public space of the street, female vendors would sell their goods, and young men would gather on the lookout for gossip or trouble. The master of the gate was the janitor, who closed the gate for the night and was informally obliged to keep order in and around the house. All interwar courtyards had outhouses and open gutters (for emptying dishwater and other wastewater). The privies were a constant focus of the Sanitary Commission, as they were often dilapidated or overfilled to such an extent that dwellers would rather relieve themselves elsewhere in the yard than use the cabins, especially in the poorer neighbourhoods. ${ }^{74}$ The odoriferous scenery of human waste and stagnating air was enriched by the smells of Lysol, carbol and lime employed by the municipality to disinfect gutters, cesspools, waste bins and apartments. ${ }^{75}$ Furthermore, the urban courtyard also was frequently used to keep animals like pigs, cows and chickens, imbuing the courtyard with the smells of their various

\footnotetext{
63 Corbin, Foul; see also M.A. Kiechle, Smell Detectives: An Olfactory History of Nineteenth-Century Urban America (Seattle: University of Washington Press, 2017); Urry, 'City Life'.

64 As part of the Public Health Department.

65 ZL, 2 Jun. 1928, 3.

66 ZL, 1 Jun. 1928.

67 The owner of a storage facility for animal bones, skins and old rags (for further processing in tanneries) for example had to pay 1000 Złoty for not removing his odoriferous store in time or accept fourteen days of arrest (Nadzór handel skór, kości, szmat i starzyna, 1929-30, APL 35220.6.2.1.2587). One of the many female mobile vendors was fined 30 Złoty for selling adulterated butter (Nadzór mleka, 1929-31, APL 352207.6.2.1.2607).

68 Interestingly, the sanitary conditions and challenges of post-war Poland are very similar to that of the pre-war period, as analysed by Ewelina Szpak, 'Warunki sanitarne w powojennej Polsce. Zarys problemów i dynamiki zmiań (1945-1970)', Polska 1944/45-1989. Studia i Materiały, 12 (2014), 277-99.

69 Sprawozdania i statystyka działalność sanitarna Magistrata 1928-1930: Higiena publiczna, APL 354030.7.2.5.392, 4.

70 Wydział Zdrowia: Porządek domowy i uliczny, 1928-31, APL 352207.6.2.1.2557, 360.

71 ZL, 5 Aug. 1931.

72 As remembered by various Lubliners - for more information see the oral history project of 'The Grodzka Gate - Theatre NN' with recollections about interwar Lublin: http://teatrnn.pl/historiamowiona/ (last visited 25 Feb. 2019).

73 See the childhood memoirs of Róża Fiszman-Sznajdman, Mój Lublin (Lublin: Wydawn. Lubelskie, 1989) and the testimonies in the oral history archive of Lublin's Grodzka Gate: see Fn 72.

74 See Porządki domowe i uliczne, 1931, APL 352207.6.2.1.

75 The report of the office for urban disinfection for the month of November 1919 indicates 58 flats disinfected with sulphur, three with formalin and one with carbol, Lysol and lime (mostly used for disinfecting toilets and gutters), see
} 
excrements. Finally, the courtyard, with its wooden sheds, served as a storage place for various goods. Among others, the Sanitary Commission frequently encountered 'agglomerations of rags and bones of an unbearable stench, ${ }^{76}$ The Commission also received letters from tenants complaining about their courtyard's pungent smellscape. 'There is an illegal tallow melting in our yard', went one such letter; 'I report that in our courtyard there is a clandestine storehouse for raw skin ... the skins are exuding an unbearable smell', noted another. ${ }^{77}$ We find complainants reporting that in our building there is a very filthy herring smokehouse, on top of that the staff empties the remaining offal and wastewater into the courtyard, wherefore the air is reeking. Furthermore, the low chimney blows its smoke through the windows into our apartments and poisons the air. ${ }^{78}$

These 'smellmarks', ${ }^{79}$ which dominated sanitary discussions in the first half of the twentieth century, also reveal the activities conducted in Lublin's courtyards. A podwórko can be understood as a microcosm of urban cohabitation: besides being animated by children at play and women on their daily errands, the space of each podwórko was defined by intimate physical needs and the emanations of various common occupations - from bakeries, ragmen, the processing of raw products, storehouses up to animal keeping - and it also served as a dumping place for kitchen, human and workshop waste. Notably, by the late 1920s and early 1930s Lublin's citizens were lodging an increasing number of complaints to the Public Health Department or Sanitary Commission regarding olfactory nuisances. This increasing smell sensitivity was the result of a major urban sanitation initiative in the framework of establishing 'Great Lublin' in 1925, which, at the same time, reflects the ideological aim of establishing a 'Polish city' strongly driven by national health concerns. ${ }^{80}$

\section{Urban Scents and Sensibilities}

The concentration of smell affairs in the local press coincided with a rise of individual citizen complaints to municipal institutions which intensified in the late 1920s (compared to the decades before and after). It is probably the raised awareness for regulation and hygiene in the context of Lublin's urbanisation efforts that generated this new (sensory) alertness. The late 1920s and early 1930s saw not only increasing odour measurements on the part of the municipality but also an emerging culture of odour complaints published in newspapers or directed to the Sanitary Commission. These citizens' claims (podanie), requests (prośba) and complaints (zażalenie) regarding urban odour nuisances and air pollution reflect an increasing odour sensitivity and alertness. ${ }^{81}$

Apart from the various exudations of workshops, food processing, outhouses and gutters shaping the 'smellscape' of Lublin's interwar courtyards that increasingly offended noses, there were frequent complaints about the keeping of animals. The proximity of animals and humans in the urban context was increasingly criticised as inappropriate for urban living and perceived as a threat to health. In 1919 the city's code of conduct prohibited the keeping of animals, particularly birds, pigs and goats, in housing space. ${ }^{82}$ In 1921 there were still hundreds of horses and thousands of cows and pigs living within the city limits. ${ }^{83}$ In their letters of complaint, people justified their sensitive sensory disposition through hygiene and health issues:

Święta czystości w Lublinie 1919-1920: sprawozdanie z działności Centrali Dezynfekcji Miejskiej za czas od 1.XI.19 r. do 23.XI.19 r., APL 352207.6.2.1.544, 15.

76 Wydział Zdrowia publicznego: 'Nadzor nad masarniami', 1925-30, APL 352207.6.2.1.2611.

77 Wydział Zdrowia publicznego: 'Porządki domowe i uliczne', 1931, APL 352207.6.2.1; see also following quotes.

78 Ibid.

79 On the idea of 'smellmark' as the olfactory equivalent to landmark, highlighting a particular aspect of a place, see Porteous, Smellscapes, 92.

80 Marta Aleksandra Balińska, 'The National Institute of Hygiene and Public Health in Poland 1918-1939', Social History of Medicine, 9, 3 (1996).

81 Porządki domowe i uliczne, 1931: Skarga mieszkańców na nieporządki i zatruwanie powietrza, APL 352207.6.2.1.

82 Gebhard, Lublin.

83 Henryk Gawarecki, O dawnym Lublinie. Szkice z przeszłości miasta (Lublin: Wydawn. Lubelskie, 1974), 226. 
I would like to report to the Sanitary Department, that M. B., living at ul.Dolna Panny Marii number 22 is keeping three cows and a number of pigs. It is known that the keeping of pigs in the city centre in unsuitable wooden huts is not allowed for hygiene and health reasons, but M. Bieniek resists these prescriptions and not only keeps cows and pigs ... but is also burying dead pigs in his garden (and I would like to add that over the last couple of weeks his pigs have been dying on him quite often). Because of the unpleasant smells coming from this cowshed and pigsty and the accompanying flies, it is impossible to sit in the neighbouring garden and it is likewise not possible to open the window to air the apartment. ${ }^{84}$

Lublin's Panna-Maria Street attracted the highest number of complaints regarding sanitary transgressions. Although located not far from the main Krakowskie Przedmieście boulevard, it retained a rural character (as it does to this day). A few houses down the same street from the complainant above, came the following report:

Honoured Doctor, I ask for understanding of the poor woman that I am, unhappy and constantly suffering from a bad headache and any pollution of the air is very harmful to me. Because I am in such a critical condition and cannot go out, I at least would like to have a little bit of fresh air from the yard, but this is difficult, because the janitor F. B. is keeping two big pigs and leaves the pigsty open all the time. ... I ask you, honoured Doctor, if you could do something about that, at least to decide that this stinking pigsty, which is located opposite my flat, at least should be kept closed, so that I could breathe at least a little bit more of a clean air. ${ }^{85}$

These complaints point to a new understanding and perceptions of what would be (olfactorily) tolerated and reflect a newly acquired or heightened odour sensitivity and odour consciousness. Smelling is an inherent bodily experience, strongly connected with ideas, beliefs and (changing) mindsets. The complaints provide insight into how recent urban changes and city authority's policies were influencing people's self-conception as urban dwellers and their role as decision makers.

It is striking that Lublin's inhabitants increasingly referred to hygiene and health and demanded 'fresh air'. The impact of public hygiene measurements, the frequent appeals in the daily press and the operations of the Sanitary Commission seemed to have raised public awareness for the regulation of the noxious and for a concept of 'public health' that included a new sensitivity for personal wellbeing, affecting the whole social spectrum of Lublin's dwellers - men, women, Christians and Jews -, as reflected in the handwriting, language style, home addresses and names on these complaints. The urban competition from 1925 also presented a significant public issue. For the first time, the question of the development of the city became a topic of public discussion. ${ }^{86}$ On their way into a 'modern' era, Lublin's citizens began to complain about rural elements interfering with the urban 'metropolitan' character of Lublin. The complaints show how the city's inhabitants both shaped and were shaped by processes of urban change. A new understanding of what was (in)tolerable boosted civic engagement. People developed a concern for 'fresh (urban) air'. Submitting complaints about odour nuisances to the press and to municipal departments indicates a turn: the municipality stepped in to regulate Lublin's (mostly organic) 'smellscapes' to shape and to create a modern city with decent infrastructure. In this atmosphere of sanitary officers instructing and penalising Lublin's inhabitants on odours, journalists and media reported on the city's smelly characteristics and urban dwellers started to claim a right to fresh air and open windows without chicken and pigs roaming about and stinking up the yard. Organic smells no longer fit the urban context. Thus, the observed increase of individual complaints alongside the demand for modern infrastructure and 'urban air' indicates the emergence of

\footnotetext{
84 Following quotations see: Porządki domowe i uliczne, 1931: Skarga mieszkańców na nieporządki i zatruwanie powietrza, APL 352207.6.2.1.

85 Ibid.

86 Przesmycka, Lublin.
} 
a new urban consciousness of being a 'city-zen' - a confident city dweller in contrast to coming from the country. The feeling of revulsion and disgust towards organic odours can be understood as a claim to a form of civility. ${ }^{87}$ These complaints, based on old 'scents' but new sensitivities, were generated by a new awareness of civic participation that reflects changing attitudes rather than changing 'smellscapes'.

\section{'Polluting Elements'}

Discussions about health helped to regulate the city's 'smellscapes' and to define private space and individual smell borders, but they also played a crucial role in the development of political and social order. Growing smell sensitivity was partly the effect of a major urban sanitation initiative. Yet smells also tend to appear threatening because they subverted 'the regulation of emotions and behaviour supposedly necessary to societal organisation' ${ }^{88}$ After 1918 the Second Polish Republic, as well as the city of Lublin, became obsessed with cleaning up, establishing order, moralising and freeing Poland's politics, as well as its inhabitants, from foul odours. Interestingly, in the public debate about urban infrastructure, the woeful legacy of Imperial Russia was hardly an issue. The interwar decades were, instead, dominated by a Polish nationalist discourse. There were fewer complaints about past smells or about stirring up old anti-Russian sentiments, but, instead, an eager push towards a future sanitised from offensive exudations and 'polluting' elements that were unsettling the atmosphere of the Second Polish Republic. This effort ranged from surveilling backward infrastructure (cleaning up the city, sanitising Lublin's courtyards and streets mostly from its pungent sewage smells and implementing major infrastructural improvements) to defining and thus deodorising 'Polish space'. Where the state had implemented more moderate and gradual reforms in the nineteenth and early twentieth centuries - as was the case in Habsburg Lemberg or Dubrovnik - civil society would emerge gradually and thus more smoothly. ${ }^{89}$ In Lublin, in contrast, the emergence of civic rights after 1918 was tied up with nationalist aspirations and fierce anti-Semitism.

Just as Lublin's municipality fought the bad odours of city courtyards which symbolised the poor state of urban infrastructure, various political parties were competing to clean up and restructure the newly born Polish Republic in terms of the foul odours of incompetence. Józef Piłsudski, Chief of the State (1918-22) and de facto leader of the Second Polish Republic (1926-35), aimed at 'cleansing' Polish politics of corruption and infighting. He complained about the 'Cloaca Maxima' of the Polish parliament with its atmosphere of nationalism and hatred, 'spreading its smells to every corner of life in Poland - a smell characteristic of the current state of the country.' 90 'Go away, you moral filth', wrote the newspaper Ziemia Lubelska about one member of the right-wing National Democrats, 'wash yourself so you don't poison the air of another city with the stench you emit'. ${ }^{11}$ Smell-rhetoric has always been a popular mode to articulate what is foul in the country. The language of cleansing was useful to define political stenches and for the conflation of 'foreign' elements in interwar Poland. The attempt to 'clean up' both Poland and the city (of Lublin) can therefore also be seen

87 Sigmund Freud stated a heightened sensitivity to odours as a byproduct of the civilising process set in motion when man adopted an erect posture (Briefe an Wilhelm Fließ, in J.M. Masson, ed., Das Unbehagen der Kultur. Gesammelte Werke, Bd.14 (Frankfurt/Main: Fischer, 1989), 459. Further readings: Maria Pirogovskaya, 'Disgust as Civility: Perception of Sanitary Nuisances in Late Imperial Russia', paper presented at 'Between Body and Mind: Emotions, Health and Medicalization', XIV Gustav Wasa Conference held at Jyväskylä, Jun. 2016; Corbin, Foul; Barnes, Great Stink; Jonas Frykman, 'Pure and Rational: The Hygienic Vision: A Study of Cultural Transformation in the 1930's: The New Man', Ethnologia Scandinavica (1981); Winfried Menninghaus, Ekel: Theorie und Geschichte einer starken Empfindung (Frankfurt/Main: Suhrkamp, 2002).

88 Drobnick, 'Toposmia', 35.

89 See Carsten Goehrke, 'Städte zwischen Ost und West. Eine vergleichende Bilanz', in Carsten Goehrke and Bianka Pietrow-Ennker, eds., Städte im östlichen Europa. Zur Problematik von Modernisierung und Raum vom Spätmittelalter bis zum 20. Jahrhundert (Zürich: Chronos, 2006), 393-410.

90 See a report on 'Marszałek Piłsudski about the election in the Sejm', ZL, 25 Oct. 1930, 1.

91 ZL, 12 Jun. 1927, 8. 
in the context of Piłsudski's 'Sanation' movement (Sanacja), ${ }^{92}$ as well as the National Democrats' platform to purge Poland from perceived threats. ${ }^{93}$ Here especially, sensory history can help to examine the way in which the senses have facilitated particularism and nationalism.

Several notions of what constituted 'polluting elements' arose in the context of defining what a Polish city should and should not look (and smell) like. General liberalisation led to more intense public debates, which intensified traditional animosities and led to more stark definitions of what constituted 'ours' and 'foreign'. The National Democrats and their daily organ Głos Lubelski, in particular, actively spread foul odours and poisonous ideas.

In the post-First World War era, health played a significant role in the formation and re-conception of nations. ${ }^{94}$ The question of health spurred nation building, as it served to integrate and exclude people, define borders and forge identities. Health and hygiene assisted the evolving political and social order of interwar Europe. As Lublin tried to establish itself as a major city of newly independent Poland, intensified Polish nationalist discourse followed. ${ }^{95}$ Here, the case of a Jewish butcher, as reported in Ziemia Lubelska, sheds light on another aspect of problematic courtyard air:

The motive for this article is by far not anti-Semitism, but the feeling for health, and views of a pure humanitarian nature. . . Imagine this picture: blood on the sidewalk of the small street, when we cross the gate, muck mixed with blood and feathers, this is the content of the yard. Inside, everything is sticky with filth, blood and feathers, everything drops to the floor which hasn't been cleaned for a long time and a rotten smell of decay spreads. . . . This is a plea to the municipality as well as to the Jewish community, who should care not only for the health of their co-confessionals, but also should not risk losing their reputation! ${ }^{96}$

This courtyard in Browarna Street was certainly neither the only Lublin courtyard nor the only butcher suffering from disastrous hygienic conditions and the 'rotten smell of decay'. Yet the article links its cry for hygiene and humanity in the name of public health to the question of 'Jewish reputation', which raises issues beyond those of smell and hygiene. Eventually, the article touches on the question of 'national health' and social order and aligns cleanliness with hygienic standards, moral rectitude and social credibility. The underlying purpose of the article is soon revealed by another note in the same newspaper just a few pages further:

For about eighty thousand Christian dwellers, Lublin does not have one Christian butcher for poultry. . . . On the market they sell poultry alive. . . In some shops, but not too many, you can buy a slayed chicken; however, only a whole one which usually is too expensive. So, there's only the Jewish butcher left - with kosher poultry. But the price here is even higher. ${ }^{97}$

\footnotetext{
92 R. M. Watt, Bitter Glory: Poland and Its Fate, 1918-1939 (New York: Hippocrene Books, 1998); Andrzej Garlicki, Piękne lata trzydzieste (Warszawa: Prószyński i S-ka, 2008); Marian Leczyk, Druga Rzeczpospolita 1918-1939: Społeczeństwo, gospodarka, kultura, polityka (Warszawa: Książka i Wiedza, 2006).

93 See on 'National Egoism' Brian Porter, When Nationalism Began to Hate: Imagining Modern Politics in Nineteenth-Century Poland (Oxford: Oxford University Press, 2000), 231 (on Roman Dmowski).

94 See Nadav Davidovitch and Rakefet Zalashik, “Air, Sun, Water": Ideology and Activities of Oze (Society for the Preservation of the Health of the Jewish Population) During the Interwar Period', Dynamis, 28 (2008); Iris Borowy and Wolf D. Gruner, eds., Facing Illness in Troubled Times: Health in Europe in the Interwar Years, 1918-1939 (Frankfurt/Main: Peter Lang, 2005).

95 This direction was strongly maintained by the emerging National Democratic Party, emphasising its nationalist character especially after 1918 and standing out through their anti-Semitic actions and constant public debate between their main press organ Głos Lubelski and the Yiddish daily Lubliner Tugblat. See also Paul Brykczynski, Primed for Violence: Murder, Antisemitism, and Democratic Politics in Interwar Poland (Madison: University of Wisconsin Press, 2016).

96 ZL, 15 Nov. 1929, 3.

97 Ibid., 4 .
} 
The proximity of this second article reframes the first as an inter-ethnic matter. Its grievance is less about the reeking courtyard and filthy butchers and more about Lublin's Christian dwellers being forced to bring their chickens to the Jewish butcher. ${ }^{98}$ It is no coincidence that these two articles appeared in close succession. Their proximity shows a tendency to denounce Jewish spaces as putrid and smelly. Anti-Jewish discourse of the time frequently introduced filth and smell to denounce the Jewish presence in the 'Polish' city. ${ }^{99}$ Here again, the author of the article engages less with the actual 'smellscapes' of interwar Lublin or smelly Jewish butchers than implements smell demarcation in order to generate images of the 'other'. Concerns about smells were at the forefront of national policy. After 1918 the idea of the nation state in East-Central Europe implied something clean, pure and homogenous. Beyond 'cleaning up' imperial legacies like infrastructural backwardness, 'cleaning up' social and political structures or ethnic plurality became more prevalent during Piłsudski's 'sanation' from 1926 onwards. ${ }^{100}$ In this process of nation building, contamination discourses around filth and contagion entailed efforts of regulation and purification. ${ }^{101}$

The idea of the East European Jew as dirty, foul-smelling and disease-carrying has long been prevalent in Western as well as Eastern European discourse. ${ }^{102}$ With the emergence of a blunt nationalistic mindset, ${ }^{103}$ Lublin's newspapers - and not only the National Democrat Głos Lubelski - increasingly addressed urban sanitary issues as well as putrefaction rhetoric. Those accused of causing inhuman pollution' were mostly inhabitants of the Jewish neighbourhood. ${ }^{104}$ Anti-Semites complaining about 'Jewish smells' is perhaps unsurprising, but it demonstrates olfactory codes classifying selfhood and otherness. ${ }^{105}$ Smell helped elaborations of class and race, ${ }^{106}$ and Polish National Democrats' discourse proves the concurrence between highly emotional national politics and the re-implementation

98 It transpires that this same butcher had already been observed and sentenced for sanitary transgression under Tsarist rule.

99 Most historical texts, memoirs and newspapers articles from the nineteenth century onwards emphasise the peculiarity of the Jewish quarter. Dominating the descriptions are miserable houses, squalor and poverty and more or less open expressions of estrangement and repulsion. See Seweryn Sierpieński, Historyczny obraz miasta Lublina (Warszawa, 1839); Seweryn Liniewski, Opis Lublina; Henryk Gawarecki, 'Porównawczy opis Lublina z lat 1822 i 1889 Seweryna Liniewskiego, in Muzeum Lubelskie, ed., Studia i materiały lubelskie, vol. 1, 1963; Majer Balaban, Die Judenstadt von Lublin (Berlin: Jüdischer Verlag 1919); Alfred Döblin, Reise in Polen (Berlin: Fischer 1924). The discourse about Jewish Lublin is dominated by anti-sanitary conditions as well as unpleasant air. See, for example, ZL, 18 Jan. 1930, 4. Lublin's newspapers of the interwar period frequently address urban sensual challenges, among them the questionable air of the Jewish neighborhood. See ZL, 24 Jul. 1929, 3. Motifs of puzzling chaos and obscure exoticism have a long tradition in memoirs and journalistic texts since the nineteenth century. Oral history testimonies about interwar Lublin also paint mostly a resentful, odoriferous picture of the Jewish neighborhood. See Marta Kubiszyn, 'Miejsce rzeczywiste miejsce wyobrażone: nieistniejąca dzielnica żydowska w Lublinie w świetle wywiadów oral history', Wrocławski rocznik historii mówionej, 5 (2015), 5-35. See also the oral history project of Brama-Grodzka - Teatr NN on Lublin's Jewish quarter before the Second World War: http://teatrnn.pl/node/146/program_historia_m\%C3\%B3wiona (last visited 24 Jan. 2020).

100 On minority politics and experienced discrimination in the interwar period, see Borodziej, Geschichte Polens, 164-9 and 179.

101 These efforts were visibly centred around the Jewish neighbourhood. See the 'disinfection' and 'desinsection' actions of the municipality described in 'Wydział Sanitarny doty.święta czystości w Lublinie 1919-1920', APL 352207.6.2.1.2544, 24. Personal recollections can be found in the pre-war memoirs of Fiszman-Sznajdman, Mój Lublin. On cleansing activities and sanitation efforts of the Jewish neighbourhood up to National Socialists' hygienic surveillance of Lublin's Jewish ghetto, see Tadeusz Radzik, Lubelska dzielnica zamknięta (Lublin: UMCS, 1999), esp. the chapters on the Sanitary Commission, 190-4 and Health Department, 194-203. For more general information on the topic of 'Jewish diseases' see Paul Weindling, Epidemics and Genocide in Eastern Europe, 1890-1945 (Oxford: Oxford University Press, 2000).

102 Ibid; Steven Aschheim, Brothers and Strangers: The East European Jew in German and German Jewish Consciousess 1800 1923 (Madison: University of Wisconsin Press, 1982), 185.

103 Dmowski's National Democratic Party was especially successful in former Russian territories, see Porter, When Nationalism Began to Hate.

104 ZL, 8 Aug. 1929, 3.

105 See Constance Classen, 'The Odor of the Other: Olfactory Symbolism and Cultural', Ethos, 20, 2 (Jun. 1992), $133-66$.

106 See Mark M. Smith, How Race is Made: Slavery, Segregation, and the Senses (Chapel Hill: University of North Carolina Press, 2006). 
of old olfactory stereotypes. This period of nation building and political tension coincided with heightened sensory sensitivities.

The general public health threats in the region - epidemics due to lack of hygiene - were commonly considered 'Jewish diseases'. ${ }^{107}$ Podzamcze - Lublin's Jewish quarter - was indeed frequently prone to outbreaks of typhus and cholera. The noticeably poor neighbourhood was located in the marshy lowlands of the city. Comprised of mostly narrow streets and flimsy, dilapidated houses, Podzamcze was the outlet for sewage that poured through the gutters from the upper town and from the city prison located on Castle Hill. But in its attempts to improve the hygiene and infrastructure of the city, the municipality neglected the Jewish neighbourhood. Lublin's Jewish community enjoyed a relatively democratic self-administrative structure and, thus, was expected to solve local problems on their own.

As suggested in another article from 1929 in Lublin's otherwise moderate Ziemia Lubelska, the 'batthe against filth and slobs' was fought not only 'in the name of health' but also 'in the name of culture and everything that we need to protect from decay, stink and infection'. ${ }^{108}$ The smell metaphors allude to miasmas of various kinds polluting and infecting the air of independent Poland. 'Foreign elements' and problematic neighbourhoods with poor infrastructure threatened Poland's, and in this case Lublin's, health and culture with stench and contagion. The notions of 'cleansing', 'sanitising' and 'hygienising' spawned urban reforms as well as nationalist prejudices. Maintaining a healthy body of a 'new nation' was a major concern of the time, reflected, for example, in the foundation of major health care societies. ${ }^{109}$ Those in power have long wielded the rationale of hygiene as a tool for social engineering and/or exclusion. ${ }^{110}$ Hence, one can interpret the issue raised in the Ziemia Lubelska article about the butchers as vocalising 'national health' by way of Jewish pollutants and the protection of Christian-Polish citizen's health.

Growing Polish self-confidence and nationalism was at odds with a multicultural and therefore multi-odorous city. Post-independence, debates about who was supposed to linger on the streets and breathe the air of 'our' 'Polish' city became prevalent in local Lublin newspapers. 'Foreign' elements, such as the Russian Orthodox cathedral and Jewish citizens strolling the streets of Lublin beyond 'their' neighbourhoods, were accused of taking away (Polish-Catholic) citizens' space to breathe. ${ }^{111}$ Jewish butchers and retailers, in general framed as potential health threats, also implied a national health threat. Nationalist animosities - and the question of who belonged to the community - were at the centre of the discourse on hygiene. ${ }^{112}$ The foul odour of decomposition, associated with backwardness in general and the Jewish neighbourhood in particular, was not welcome in an atmosphere of modern urban living or as part of national standards. One facet of democratisation and 'citizenisation' was the fact that more Jews were leaving their (cramped) neighbourhoods to walk on the prestigious Krakowskie Przedmieście with its coffeehouses and pleasant stores or in the city park spaces that were now defined as explicitly 'Christian'. ${ }^{113}$ Some fellow citizens perceived Jewish civic and spatial emancipation as a form of 'contamination'. Polish newspapers repeatedly complained about 'smelly Jews' that would congest the streets of 'our city', or remark that the city park - 'our beautiful reservoir of fresh air' - was 'jammed with the "chosen people"' wherefore 'a bad smell of sweat, garlic and onion hovers in the air.. ${ }^{114}$ Complaints about 'the Jewish domination of the city with their

\footnotetext{
107 Weindling, Epidemics.

108 ZL, 8 Aug. 1929, 3.

109 Among others the Association of the Health Protection for the Jewish People TOZ (Towarzystwo Ochrony Zdrowia Ludności Żydowskiej).

110 David Howes, Empire of the Senses: The Sensual Culture Reader (Oxford: Bloomsbury Academic, 2005), 267.

111 See for example: 'Our Palestine - How the Jews Treat Us in Our City', GL, 5 Jun. 1923, 2; 'Our Beautiful Reservoir of Fresh air is Overfilled by the 'Chosen People', GL, 28 Aug. 1923, 3; 'And Yet, You Can't Get Off the Filth!', ZL, 8 Aug. 1929, 3; 'A Smelly House From the Ghetto', ZL, 28 Jan. 1930, 3; 'A Children's Garden Instead of the Blown Up Orthodox Cathedral', ZL, 13 Apr. 1926, 4; 'Lublin's Lung', GL, 22 Jun. 1926, 3.

112 See also Mary Douglas, Purity and Danger: An Analysis of Concepts of Pollution and Taboo (London: Routledge 2013).

113 GL, 10 Aug. 1916, 3.

114 GL, 28 Aug. 1923, 3.
} 
extreme sloppiness and enormous screaming' ${ }^{115}$ invariably carried the notion of sensory 'contamination'. Sensory impropriety (someone talking too loudly, cramming the streets or public benches or emitting odours) could be perceived as a social violation and, in the Polish post-war context, as a violation of the clean body of the Polish nation state (as envisioned especially by the National Democrats).

Exploring smell discourses, smell rhetoric, the wording around olfactory matters also requires an exploration of the history of mentalities. ${ }^{116}$ Ideological and ethnic demarcation or 'othering' can be a profoundly sensorial process. The Second Polish Republic was striving for the air of independence and saw itself fighting 'suffocation' and 'odoriferous elements' in the name of the 'modern' nation state. In this case, the call for a Christian poultry butcher in the name of (national) public health and cleanliness, as opposed to the Jewish one - a smelly, filthy and pricy place - indicates a quest for general (olfactory) cleansing. One can also read laws and regulations as attempts 'to foist disciplinary regimes to control the foreign, the poor and visible minorities'. ${ }^{117}$ The discussions about the kosher butcher and the 'inhuman pollution' of the Jewish neighbourhood and about turning up noses at Jews contaminating Christian space encapsulate the contemporary mindset of regulation and disciplining methods to clean up 'Great Lublin' also in terms of social or ethnic smells and/or filth and national health threats.

\section{Conclusion}

By focusing on the air and odours of Lublin's interwar courtyard, we can observe what was regarded as part or not part of a 'modern' city of independent Poland after the First World War. Disciplining the urban smellscape was a major issue for the emerging city of Lublin in the interwar period. Odour-free cleanliness in the name of public health served as an argument to discuss neighbourly relationships, standards of urban (co-)habitation and definitions of 'rural' and 'urban' space as well as air. The modern urban dweller claimed his right to fresh air without organic odours interfering with urban lifestyle.

The battle evolving around open windows and foul animal smells, resulting in a flood of citizens' complaints directed to city authorities in the late 1920s, also highlights the emergence of a new civic self-conception of Lublin's urban dwellers. By complaining about various stinks and claiming fresh air, they were making use of civic rights in the wake of 'citizenisation' in the Second Polish Republic.

Additionally, claiming air and space was a main feature of civic and national public discourse in the years following the First World War. Lublin municipality's drive to clean up the city dovetailed with national aspirations, deploying old stereotypes ('smelly Jews') in the new context of a modern 'clean' city and 'well-aired' Polish Christian space. Hence, Lublin's courtyard also became a battlefield of interethnic and national sensitivities.

In this context, one can understand public health as a major ideology and condition for a new functioning (national) state maintained by municipal actions as well as by city dwellers' claims. The 'new' (olfactory) sensitivity of interwar Lublin shows that hygienisation and deodorisation in the realm of urban reform discourse and urban regulation also contained a strong element of national health discussion and interethnic 'regulation'. In the process of gaining independence, the question of who belonged to the community was reasoned through order and odour. ${ }^{118}$ This odoriferous sentiment is not exclusive to the city of Lublin but characteristic of a dominant discourse of the time and region.

In general, smells became increasingly politicised: this odorous atmosphere involved political parties spreading foul ideologies and mindsets about 'polluter-Jews'. Modernisation went alongside aspirations towards a 'clean' Polish nation and raised awareness about urban (odour) nuisances. Public organs like newspapers made prevalent discourses more visible and prone to broader

\footnotetext{
115 Ibid.

116 See Robert Rogerson and Gareth Rice, 'Making Sense of Places: “Moral Geographies” of Sensory Urbanism', Architectural Theory Review. Special Issue: Sensory Urbanism, 14, 2 (2009), 14.

117 Reinarz, Past Scents, 206; see also Corbin, Foul.

118 See also Douglas, Purity and Danger.
} 
dissemination and public awareness. Exudations of neglected infrastructure or of ethnic plurality were not welcome in the process of setting modern urban living standards and national standards. ${ }^{119}$ Literally and symbolically, references to bad air and foul odours informed political, ideological and ethnic distinctions. Smells remained authoritative and deeply implicated in iterations of class, race and ethnicity in twentieth-century conversations about who and what smelled and why. ${ }^{120}$ This combination of embodied experience and emotionalised discourse regarding smells holds an important key to understanding historical change generally and reconfigurations in cultural attitudes specifically. ${ }^{121}$

Acknowledgements. This article was written in the framework of a "POLONEZ"-Fellowship (National Science Centre, Poland) at UMCS Lublin, Poland. The project (2016/21/P/HS3/04063) has received funding from the European Union's Horizon 2020 research and innovation programme under the Marie Skłodowska-Curie grant agreement No.665778. Open Access funding was provided by the University of Vienna/Institute of East European History.

119 'The imperative of sanitization was introduced in both metaphorical and literal terms with regard to the bodies, minds and mindsets of diverse people and populations.' In Howes, Empire of the Senses, 267.

120 See Smith, Sensory History, 60; Gale Peter Largey and David Rodney Watson, 'The Sociology of Odors', American Journal of Sociology, 77, 6 (1972), 1021-103.

121 See Connie Y. Chiang, 'The Nose Knows: The Sense of Smell in American History', The Journal of American History, 95, 2 (2008), 405.

Cite this article: Weismann S (2021). Scents and Sensibilities: Interwar Lublin's Courtyards. Contemporary European History 30, 335-350. https://doi.org/10.1017/S0960777320000648 